\title{
SERIAL MANAGEMENT
}

Kim S. Robinson

The control and management of serials in libraries is a vital aspect of maintaining of a library service. Serials are often the neglected poor cousins of the collection. They are often the first to go in times of financial cutbacks.

Their importance in the collection should not be underestimated. They record the forefront of theological thinking and it can take from five to ten years for the research published in them to filter through to monographic literature. The control and management of the serial collection presents librarians with a range of issues not encountered with the monographic collection.

This article will try to address some of these problems and offer some help towards their solution.

\section{SELECTION}

The selection of serial titles to be added to a collection is part of the normal selection processes undertaken by the librarian or those appointed to make the selection decisions.

If there is a written collection development policy this would in part address the issues involved in the selection of new serial titles. The criteria detailed in the policy would be used to evaluate new titles. Without a formal collection development policy selection has to rely on the librarian's understanding of the institutions aims and directions.

There will always be recommendations by the Faculty, Library Committee and users, as well as the constant stream of new titles being published. These will have to be evaluated against those issues mentioned above and the current budget constraints

There are a number of different types of serial publications and each library should try to cover, in varying degrees, these types:

1. Scholarly titles. A selection of the major scholarly titles should be included for the institutions main teaching areas. Examples of such titles are Vetus Testamenium; Novum Testamentum; Journal of Theological Studies; Church History. As so much major research is carried out in Europe consideration of a number of European language titles will have to be made. The research needs of the Faculty should be covered at an appropriate level.

2. General religious titles. A selection of current interest titles should be included in each collection. These will cover aspects of current affairs, popular religious movements and general interest issues in the church both in Australia and overseas. Examples of this type are Tablet; Christianity Today; National Outlook; On Being. Titles of a more general nature in areas not covered by the institution's teaching programme may also be included to assist the users in gaining a broader theological outlook.

3. General non-religious titles. The library may wish to subscribe to such titles as Time 
or the Bulletin and to the local newspapers.

4. Denominational titles. Each library associated with a particular denomination must decide at which level it will collect those serials closely associated with their

denomination. Attention should be paid to both the local and international scene.

\section{ORDERING}

\section{Bibliographical details:}

Periodical indexes: e.g. ARI, Religion Index One, Catholic Periodical Index, APAIS. These are important sources of bibliographical information. They also indicate which titles are considered important enough for indexing thus giving assistance in selection.

Union lists: e.g. Aulots, NUCOS, BTI Union List of Serials. These will give bibliographical information They will be of help also in the selection process by giving the locations of titles under consideration if regional rationalisation is an issue.

Published bibliographies: e.g. Eugene Fieg / Religion journals and serials: an analytical guide. New York: Greenwood Press, 1988; Charles Lippy /Religious periodicals of the United States: academic and scholarly journals. New York: Greenwood Press, 1986. These publications will often give critical assessment of titles. General bibliographies of religious material (e.g. Robert Kepple / Reference works for theological research. 3rd edn. Lanham. MD.: University Press of America, 1991. J. Gordon Melton and Michael A. Koszegi / Religious information sources : a worldtoide guide. New York: Garland Pub., 1992. Michael J. Walsh /Religious bibliographies in serial hiterature: a guide. Westport, CT., 1981.) are helpful for their coverage of serial tools rather than listing serial titles. Specialised subject bibliographies will often include suitable serial títles.

General directories: e.g. Ulrich's International Periodical Directory and the published catalogues of subscription agencies such as Blackwells and Ebsco Australia. The agency catalogues tend not to supply bibliographical details, but they do include the latest pricing information.

\section{Sources of supply:}

Once titles have been selected for ordering and bibliographical details ascertained the choice has to be made of where to purchase:

1. Agencies: Local, e.g. Ebsco Australia; Open Book or Overseas, e.g. Harrasowitz; Blackwells Periodicals Division; Dawson

2. Direct to the publishers.

The choice of the use of agencies over direct subscriptions needs to be looked at closely. The cost savings in subscribing directly may be lost in the time spent writing individual cheques or obtaining bank drafts, ensuring continuity of subscription and chasing missing issues.

A further source of obtaining titles is by donation. The donation of titles by the publishers is usually limited to the newsletter and promotional type of material. These can be useful and publishers should be encouraged to send their material to libraries. A more 
problematic kind of donation is the individual gift to a library. The support of library users to assist in the growth of the collection is something we should all be actively pursuing but it can have a large number of problems associated with it. Conditions imposed on the gifts, continuity in the supply of titles and the lop-sided nature of this type of growth have to be considered before acceptance of the offer.

\section{RECORDING}

\section{Account details:}

A record needs to be kept detailing the source of supply of each title, the cost of each year's subscription and when the subscription was paid. This is vital to easily identify the supplier and to keep a record of the price variations over the years. Such statistical information helps in budgeting.

\section{Receipt:}

Mantual e.g- index card systems - detailing each issue as it is received.

Computer systems e.g. Dedicated systems by the major software suppliers or ad-hoc in-house systems. The serials module of most library software packages is usually the last developed and always the most complex.

\section{Missing issues;}

Care needs to be taken, especially in manual systems, that missing issues are not overlooked. Prompt action needs to be taken to claim missing issues. Publishers often have time limits on when missing issues can be claimed. There is a need to check all records for the title which for some reason ceases to be supplied and is not otherwise picked up until a user draws it to our attention. This should done $2-3$ times per year.

\section{Display:}

New issues should be placed in a public area for display when they arrive. This helps users to keep up to date with what is current and shows the range of titles received by the library. Appropriate display furniture should be placed in an area with comfortable seating to encourage the users to regularly browse the recent additions.

\section{Lending policy:}

Decisions need to be made as to whether serials will be lent or not. If they are allowed to be borrowed a different time period to the books might need to be considered. New issues could also be circulated to factity members. Possibly circulation of table of contents lists may be a better way to cover this.

\section{CATALOGUING AND STORAGE}

Are titles to be fully catalogued into the main collection or kept as a separate collection, arranged by titie or call number? Should there be a separate catalogue for the serials or should they be included with the main catalogue cards? The extent of the subject cataloguing needs to be addressed.

Should all back runs be left on the open shelves or should some be placed into a stack 
collection? If the decision is made to create stack collection the decision as to which titles should be included will need to be made on a title by title basis. The current usage of individual titles will vary considerably and this prevents a hard and fast rule being adopted.

\section{BINDING}

Will the library bind some or all of the collection, which titles will be bound and when should this occur? The cost of binding will dictate the extent to which binding is carried out in most libraries. Binding needs to be done at times of least usage.

\section{RATIONALISATION}

This will occur at both the selection stage of management and each year upon receipt of renewal notices. The annual consideration of budgeting will demand that the subscription lists be constantly reassessed. Cost factors should not be the only criteria for this reassessment. Such issues as the use the title receives and other locations of it will need to be looked at in conjunction with the cost factor.

\section{DUPLICATES}

The recording of duplicates and the issue of duplicate exchange lists has been considered a number of times in previous conferences and will continue to concern us. Duplicate material can occupy a large amount of valuable space in a library. Prompt and appropriate disposal of this material is vital. Once duplicate lists have been circulated, unclaimed material may need to be discarded. Care must be taken that unique material is not disposed of at this time. The possibility of a central depository for duplicate material is an issue which should be addressed at a future conference.

\section{PROBLEMS}

The issues coyered so far are those associated with the nature of our institutions and the management of a particular type of library material. My major problem with serials lies not with us as librarians or with serial maintenance in our collections but with the very nature of their publication. They are more often than not schizophrenic, suffer major problems with their age and often are extremely tardy in keeping appointments.

Their schizophrenic nature is firstly displayed in the name of the items under discussion. Are they serials, journals, periodicals or magazines? It is also displayed in the frequent problems associated with their titles. Publishers often appear to tave no regard for librarians in the frequency of title changes or in minor variations to titles. They also often will display uncertainty as to what the serial is called within a particular issue the cover title, the running title and that in the publication details will often show vatiations. The use of volume numbering is frequently erratic and stated publication schedules are often far from the reality of actual receipt.

Despite these frustrating idiosyncrasies we should strive to provide our users with well maintained collections of these most valuable resources.

Kim Robinson is Librarian at Moore College, Sydney 